\title{
Література:
}

1. Бурняшева Л. А., Газгиреева Л. Х. Духовный кризис ценностных оснований: социально-философский дискурс проблемы / Перспективы науки. 2011. №. 2. С. 52.

2. Нибур Райнхольд / Митрохин Л. Н. / Новая философская энциклопедия : в 4 т. / пред. науч.-ред. совета В. С. Стёпин. - 2-е изд., испр. и доп. Москва. 2010. С. 2816.

3. Baetz, M., Bowen, R., Jones, G., \& Koru-Sengul, T. How spiritual values and worship attendance relate to psychiatric disorders in the Canadian population.The Canadian Journal of Psychiatry. 2006. № 51(10). P. 654-661.

4. Glas G., Poort Z. Anxiety, anxiety disorders, religion and spirituality. Southern medical journal. 2007. T. 100. №. 6. P. 621-625.

5. Hills, J., Paice, J. A., Cameron, J. R., \& Shott, S. Spirituality and distress in palliative care consultation. Journal of palliative medicine. 2005. № 8(4). P. 782-788.

DOI https://doi.org/10.30525/978-9934-588-80-8-1.23

\section{ПОКАЗНИКИ СТАНУ СФОРМОВАНОСТІ СОЦІОКУЛЬТУРНИХ ЦННОСТЕЙ СТУДЕНТІВ ЗВО У СУЧАСНИХ УМОВАХ}

\author{
Заредінова Е. Р. \\ кандидат педагогічних наук, дочент, \\ старший науковий співробітник лабораторії морального, \\ громадянського та міжкультурного виховання \\ Інститут проблем виховання \\ Національної академії педагогічних наук України \\ м. Київ, Украӥна
}

Формування ціннісно-смислової сфери особистості $є$ актуальним напрямом сучасної освіти. Аксіологічна сфера $\epsilon$ регулятором й мотиватором поведінки особистості, а соціокультурні цінності, що відбивають культурні досягнення суспільства, а також притаманну даній культурі ментальність й унікальність - ії суттєвим складником. Отже в соціокультурних цінностях синтезується суспільне, культурне й особистісне. Доцільність й важливість дослідження саме соціокультурних цінностей особистості детермінують глобалізаційні та євроінтеграційні виміри сучасного суспільства. 
3 урахуванням концептуальних ідей системного підходу та вікових особливостей студентського віку (завершення процесу зростання й входження в фазу зрілості, індивідуалізація та стабілізація пріоритетних якостей особистості; зміни у самосвідомості, в емоційновольовому устрої життя; завершення становлення світогляду; розвиток ціннісно-смислової сфери студента, які привласнюють соціокультурні цінності) у розділі обгрунтовано та розроблено структуру соціокультурних цінностей студентів ЗВО.

Виокремлено дві позиції, на яких базується обгрунтування структури соціокультурних цінностей студентів ЗВО. Перша - базується на структурно-діяльнісній ознаці, яка узасаднюється на психологічній структурі діяльності. У цьому контексті структура соціокультурних цінностей містить мотиваційно-ціннісний, когнітивний, праксіологічний компоненти.

Мотиваційно-ціннісний компонент соціокультурних цінностей $\epsilon$ сукупністю ціннісних спонук до дії, ціннісних інтересів, ціннісних ідеалів, ціннісних орієнтацій, ціннісних установок; когнітивний компонент містить систему аксіологічних знань, які $\epsilon$ теоретичною базою формування соціокультурних цінностей студентів ЗВО й пов'язані 3 рефлексією як відображенням себе, свого внутрішнього світу й власної поведінки у свідомості особистості; праксіологічний компонент соціокультурних цінностей відбиває реалізацію соціокультурних цінностей студентів ЗВО в конкретній діяльності та поведінці й представлений уміннями, діяльністю та суб'єктними феноменами особистості студента.

Друга позиція у визначенні структури соціокультурних цінностей пов'язана 3 їх типами. Відповідно до цього підходу структура зазначеного феномену містить соціокультурні макроцінності; соціокультурні мезоцінності; соціокультурні мікроцінності.

Визначено, що соціокультурні макроцінності $є$ базовими цивілізаційними цінностями, що передбачають ціннісне ставлення до культур та традицій інших народів і представників етнічних та соціальних груп; ціннісне ставлення до комунікації та взаємодії з представниками інших національностей відповідно до їх культури. Соціокультурні мезоцінності пов'язані 3 ціннісним ставленням студентів до менталітету та ментальності, сучасних культурних надбань та традицій українського народу загалом і культурної спадщини певних регіонів України. Соціокультурні мікроцінності студентів ЗВО є синтезом таких особистісних цінностей, як-от: патріотичні цінності, національно-культурна ідентичність, професійні цінності, ціннісне ставленням до себе та інших людей. 
Відтак, обгрунтована в дослідженні структура соціокультурних цінностей студентів ЗВО є синтезом зазначених наукових позицій, що полягає у зв'язку мотиваційно-ціннісного, когнітивного, операційнодіяльнісного компонентів 3 типами соціокультурних цінностей. Тобто кожний компонент соціокультурних цінностей буде трактуватися відповідно до окреслених типів соціокультурних цінностей.

На засаді розробленої структури соціокультурних цінностей обгрунтовано критеріальний апарат дослідження.

3'ясовано, що мотиваційно-ціннісному компоненту соціокультурних цінностей відповідає мотиваційно-аксіологічний критерій (ціннісне ставлення до культур та традицій інших народів і представників етнічних та соціальних груп; потреба у комунікації та взаємодії 3 представниками інших національностей на засаді міжетнічної, міжкультурної толерантності; мотивація усвідомлення менталітету та ментальності українського народу; мотиви, пов'язані з вивченням культурних надбань та традицій українського народу; ціннісне ставлення особистості до своєї Батьківщини, мотив ідентичності і почуття приналежності до української нації; ціннісне ставлення до майбутньої професії, потяг до професійної самореалізації; ціннісне ставлення до себе (Я-концепція, самооцінка); ціннісне ставлення до взаємодії, спілкування з іншими людьми на засаді емпатії як форми раціонально-емоційно-інтуїтивного відображення іншої людини (за В. Бойко); когнітивному - когнітивно-рефлексивний критерій (знання культури та традицій інших народів, а також побудови ефективної взаємодії з представниками різних національностей; знання культури та традицій українського народу; знання базових цінностей сучасного українського суспільства; знання сутності патріотичних цінностей; знання про аксіологічні аспекти майбутньої професії; самоусвідомлення власного «Я», самооцінка; знання про внутрішній світ інших людей та їх ставлення до себе (комунікативна рефлексія); знання щодо координації спільних дій у певному соціумі (кооперативна рефлексія); праксіологічному - суб'єктно-діяльнісний критерій (досвід діяльності на основі реалізації соціокультурних цінностей; готовність комунікувати та взаємодіяти 3 представниками інших національностей; уміння організувати свою діяльність суголосно базовим цінностям сучасного українського суспільства; діяльність на благо своєї Батьківщини на основі патріотичних цінностей; реалізація в освітньому процесі 3ВО ціннісного ставлення до майбутньої професії; уміння здійснювати самоаналіз власної ціннісної сфери, своїх учинків та відносин; уміння аналізувати внутрішній світ «інших», їх ставлення до 
себе 3 позицій ціннісного досвіду; уміння будувати партнерські стосунки з іншими людьми на основі «суб'єкт-суб'єктної взаємодії»).

Відповідно до окреслених критеріїв та показників, представлено три рівні сформованості соціокультурних цінностей, а саме: низький, середній, високий.

Розроблено діагностичний інструментарій визначення рівня сформованості соціокультурних цінностей, що грунтується на синтетичному використанні окремих шкал, показників таких відомих стандартизованих методик, як опитувальник «Вивчення цінностей особистості Шварца» (шкала - універсалізм); методика «Вивчення ціннісних орієнтацій» (П. Степанова) (шкали: відношення до людини як до Іншого (толерантність), цінність людини, альтруїзм-егоїзм, відношення до свого тілесного Я, відношення до свого внутрішнього світу) та ін., а також авторських анкет «Визначення соціокультурних цінностей за мотиваційно-аксіологічним критерієм», «Визначення соціокультурних цінностей за когнітивно-рефлексивним критерієм», «Визначення рівня сформованості соціокультурних цінностей за суб'єктно-діяльнісним критерієм».

3 метою дослідження рівнів сформованості соціокультурних цінностей студентів, а також з'ясування чинників, які впливають на їх формування у студентському віці, був проведений констатувальний експеримент. У експериментальному дослідженні взяли участь студенти Винницького державного педагогічного університету ім. М. Коцюбинського, Уманського державного педагогічного університету ім. П. Тичини, Ізмаїльского державного гуманітарного університету, Д3 «Луганський національний університет ім. Т. Шевченка», Кам'янецьПодільского національного університету ім. І. Огієнка, Вищого комунального навчального закладу «Користишівський педагогічний коледж ім. І. Франка». Загалом в експериментальній роботі прийняли участь 837 студентів, 168 викладачів. При цьому на початку експерименту всіх студентів було поділено на контрольну (КГ) та експериментальну (ЕГ) групи. При цьому в КГ увійшли 420 студентів, в ЕГ - 417 студентів.

Метою констатувального етапу експериментальної роботи було вивчення загального рівня сформованості соціокультурних цінностей студентів.

У процесі проведення констатувального експерименту доведено, що у студентів першого курсу переважає розвиток показників соціокультурних цінностей за мотиваційно-аксіологічним критерієм, так у більшості респондентів превалює середній рівень сформованості соціокультурних цінностей $(55,48 \%$ - КГ та 55,16\% - ЕГ) з тенденцією до підвищення $(23,57 \%$ - КГ та $23,26 \%$ - ЕГ). Низький рівень розвитку 92 
соціокультурних цінностей за мотиваційно-аксіологічним критерієм діагностовано у 17,14\% досліджуваних КГ та $17,51 \%$ - ЕГ. За когнітивно-рефлексивним критерієм у першокурсників діагностовано високий рівень сформованості соціокультурних цінностей у 20,24\% (КГ) та 29,14\% (ЕГ); середній рівень - у 46,19\% (КГ) та 45,56\% (ЕГ); низький рівень виявлено у 33,81\% респондентів КГ та $34,53 \%$ - ЕГ, тобто переважає середній рівень. Показники розвитку соціокультурних цінностей за суб'єктно-діяльнісним критерієм знаходяться переважно на низькому $(48,33 \%$ - КГ та $51,08 \%$ - ЕГ) та середньому $(40,71 \%-$ КГ та 39,09\% - ЕГ) рівні. Високий рівень виявлено лише у 11,19\% першокурсників КГ та $11,27 \%$ - ЕГ. Слід зазначити, що розподіли рівнів сформованості соціокультурних цінностей за мотиваційно-аксіологічним, когнітивно-рефлексивним та суб'єктно-діяльнісним критеріями у студентів КГ та ЕГ на констатувальному етапі експерименту значущо не відрізняються між собою, що було доведено з допомогою методів математичної статистики.

Констатовано, що у першокурсників у більшій мірі сформоване ціннісне ставлення до соціокультурних цінностей та проявляються мотиви та потреби пов'язані з поглибленням знань щодо соціокультурних цінностей та мотивації їх реалізації. Рівень сформованості соціокультурних цінностей за когнітивно-рефлексивним критерієм у студентів заходиться переважно на середньому рівні, тобто знання щодо соціокультурних цінностей ще $\epsilon$ недостатньо глибокими та стійкими. Розвиток рефлексії також є недостатнім. Найбільш низькі результати спостерігаються за суб'єктно-діяльнісним критерієм, тобто першокурсники ще не мають достатніх знань, умінь та збірностей для цілеспрямованої реалізації соціокультурних цінностей, що проявляється в недостатньому розвитку суб'єктності, мотивації професійної діяльності, здібностей до самоаналізу та аналізу оточуючої дійсності. 